\title{
Bacterial biofilm on PLA film and methods of its identification
}

\author{
Agnieszka Richert*, Grażyna B. Dąbrowska \\ Nicolaus Copernicus University in Torun, Faculty of Biology and Veterinary Sciences, \\ Chair of Genetics, Lwowska 1, 87-100 Torun, Poland \\ *corresponding author e-mail: a.richert@umk.pl
}

Received: 31 March 2020 / Accepted: 20 April 2020

\begin{abstract}
This paper presents a brief characterization of bacterial biofilm, formed on polylactide, ecologically important biodegradable material. The concept of bacterial biofilm was explained, including the process of its formation as well as the structure and model of functioning in a biological environment. Three methods of its determination and documentation by spectrophotometric measurement, live/dead test using fluorescence microscope and surface structure analysis using scanning electron microscope were presented.
\end{abstract}

Keywords: biofilm, biodegradable films, PLA, Escherichia coli, Staphylococcus aureus, Salmonella enteritidis, Bacillus subtilis.

\section{Introduction}

On biotic and abiotic surfaces, including packaging and films can be deposited microorganisms. They have developed mechanisms that allow them to survive in different environments. Adaptation and survival in the environment is the result of bacterial cell reaction to stress, during which changes in their metabolism occur and launch, among others strict response and production of alarmons, atypical nucleotides, guanosine tetra- and pentophosphate (Dąbrowska et al., 2006). Accumulation of alarms, in response to stress, is accompanied by, among others changes in the physical state of the lipid bilayer of the cell membrane, which stimulates the production of autoinductors, which in turn enables the formation of a biofilm, thereby increasing the survival of microorganisms and promotes their resistance to antibacterial substances (Berdychowska et al., 2019).

Microorganisms adhere to the surface and form layers called biological membranes or biofilms. This allows them easier access to nutrients, and also protects cells from the negative effects of environmental factors. The adhe- sive capacity of microorganisms have a huge impact on the ability to cause infections and impurities (Baranowska \& Rodziewicz, 2008). Biofilm is defined as a multicellular structure surrounded by a layer of organic and inorganic substances produced by the microorganisms that form it, showing adhesion to biotic and abiotic surfaces (Czaczyk \& Wojciechowska, 2003). These cells adhere to each other and to solid surfaces. Bacterial cells living in a biofilm environment show resistance to a significant part of antibacterial agents and are about 1000 times more resistant to the action of these agents than suspended microorganisms (Trafny, 2000).

The formation and formation of a biofilm is a complex process, depending on the type and properties of the microorganisms that form it, as well as the structure, composition and properties of the colonized material. There are several stages in the process of biofilm formation: (a) initial (reversible) adhesion, (b) irreversible adhesion of microorganisms, (c) microcolony formation (growth and maturation), (d) mature form, e) biofilm dispersion (Fig. 1) (Kołwzan, 2011). Stage one is adhesion. Extracellular polymers and lipopolysaccharides play an important 
role in this stage and proteins of their cell wall, as well as extracellular structures: cilia and fimbriae. The material's surface structure (smoothness, roughness) and mechanical damage (Czaczyk \& Wojciechowska, 2003) are of great importance for material settlement.

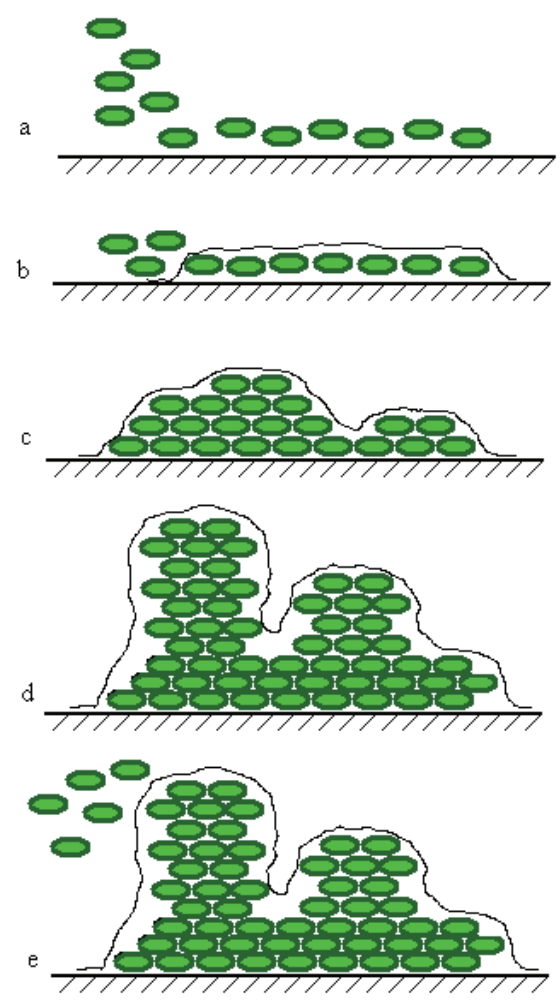

Figure 1. Scheme of formation of biofilm (Kołwzan, 2011)

Deposition of bacteria on the medium occurs in a basic and essential way. In the basic phase, microorganisms are not permanently attached to the substrate, which makes it relatively easy to remove from it. Some microorganisms are detached from the ground freely or by physical or chemical means (Czaczyk \& Wojciechowska, 2003).

At a distance of about $3 \mathrm{~nm}$ from the ground, the main phase begins, in which chemical forces play the main role: hydrogen bonds, formation of vapor and ionic complexes, covalent bonds and exopolymers produced by bacteria. It is an irreversible phase in which the removal of microorganisms from the substrate requires complex chemical treatments (bacterial cell death) or by mechanical removal from the surface. External structures of bacteria such as cilia or fimbria are extremely important in the process of colonization of a given surface (Kunicki-Goldfinger, 2008).

In the irreversible phase, microorganisms multiply, form micro-colonies and differentiate them. There is a static division of cells in a given place, as well as the migration of individual cells on the surface, resulting in larger clusters. The first microcolonies are a layer of 3-5 cells, often dispersed as a layer of microorganisms adjacent to the substrate. In contrast, the mature biofilm is surrounded by a thick layer of glycocalyx to which mineral substances, organic compounds and other organisms are adsorbed (Trafny, 2000).

Biofilm may form both mono- and multi-layer, it can create a micro-organism one or more species. There are three types of biofilm structure: flat, otherwise known as two-dimensional, characteristic in an environment with a strong flow of aqueous solution), columnar and so-called mushroom model, noticeable at slow water flow (Flemming \& Wingender, 2010). The spatial structure of the biofilm depends on many factors, such as hydrodynamic conditions, nutrient content, bacterial mobility, intercellular communication, content of exopolysaccharides and proteins.

The biofilm forming microorganism cells are connected to each other by an extracellular polymeric substance composed mainly of exopolysaccharides (EPS). Its components play an important role at the beginning in the creation, then in the functioning of the biofilm. Extracellular biopolymers also protect the biological membrane by preventing direct access of the disinfectant to bacterial cells (Hall-Stoodley et al., 2004).

The excretion of metabolic products, as well as the supply of nutrients to microorganisms, is possible through a network of channels found in biofilm. Rampholipids are responsible for their proper functioning. This system allows only metabolic active cells to function properly, allowing the thickness of the biofilm to increase, and these are found in the surface layer of the microcolony. The inner layer of the microcolony contains cells in anabolic state, and in the deeper layers there are extracellular substances that interfere with its proper functioning. Intracellular signaling, which consists in the production of signal molecules and their free diffusion between cells, is responsible for the proper functioning of the biofilm. The phenomenon of communication and recognition of the number of cells (sensing cell density) in a biofilm is called quorum sensing - QS. The ability to convey intercellular information means that biofilms can function as primitive multicellular organisms (Czaczyk \& Myszka, 2012).

The layer most exposed to damage, both mechanical and biocidal, is the biofilm surface. Many bacteria have a coating or mucus on the outer surface of the cell wall. It creates a barrier, protecting the cell from drying out and phagocytosis, reduces the rate of diffusion of biocides through biofilm layers and plays an important role in the processes of cell adhesion to the surface of solid materials. A large amount of polysaccharides in the shell increases the number of free functional groups, which also causes high resistance of microorganisms.

Bactericide resistance to bacteria can be due to the activity of proteins with cell pump properties that recognize a variety of hazards and remove them from the cytoplasm. Environmental factors are also important. The cells in the 
deeper layers of the biofilm have much less nutrients and oxygen, which leads to a reduction in growth rates and a reduction in sensitivity to toxic substances. The slowed growth protects the cell against the action of antimicrobial substances. Metabolic changes in biofilm cells may be the reason for the high resistance of biological membranes to bactericidal substances.

In addition, some cellular enzymes are able to modify the structure of bactericidal substances and thus change their properties and potency. Some scientists also believe that biosurfactants (e.g. rhamnolipids) increase biofilm resistance to phagocytosis and participate in infectious processes (Flemming \& Wingender, 2010).

Bacterial biofilm is a structure that protects cells from bactericidal substances. In addition to its protective function, it also plays a huge role in the initial biodegradation phase. Contamination of polymeric materials is the beginning of biodegradation (Kania-Surowiec, 2013). The processes of destruction of materials that occur under the influence of biological activity are referred to as biodeterioration or corrosion caused by microorganisms (MIC-microbiologically influence corrosion). Colonization of the surface of materials is easier when, due to the action of wind, water and air pollution, there is a violation and damage to the structure (Kołwzan, 2011). Water easily gets into the damage, which contributes to the settlement of microorganisms on the surface of the material. Initially, it is covered with individual cells, but over time they begin to multiply and create colonies that form a mature form of biofilm (Czaczyk \& Wojciechowska, 2003). Its presence is not without significance for biodegradation processes.

Different groups of microorganisms can break down or transform organic compounds into simpler substances. Microorganisms and their enzymes as well as external factors such as oxygen concentration and biofilm density affect the processes and rate of decomposition of a given organic material (Kania-Surowiec, 2013). The aim of the work is to check the ability of selected bacterial strains to create a biofilm and its identification on the surface of polylactide, an ecologically important biodegradable polymer material, commonly used in the packaging industry.

\section{Material and methods}

The basic research material was a flat film made of polylactide PLA (Ingeo ${ }^{\text {TM }}$ Biopolymer 2003D, Nature Works ${ }^{\circledR}$ LLC, USA), which was subjected to various methods of biofilm determination, which include spectrophotometric measurement, live/dead test using a fluorescence microscope and surface structure analysis using a scanning electron microscope.

Determination of bacterial biofilm by spectrophotometric measurement of the amount of bound crystal violet by biofilm forming bacterial cells (Kroupitski et al., 2009; Sela et al., 2006; Stepanovic et al., 2000) were performed based on four bacterial reference strains: Escherichia coli (ATCC 8739), Staphylococcus aureus (ATCC 6538P), Salmonella enteritidis (ATCC13076), Bacillus subtilis (ATCC6633) (Microbiologics $®)$. Bacteria were grown on nutrient broth composition $\left[\mathrm{g} / \mathrm{dm}^{3}\right]$ : peptone -5.0 , meat extract -3.0 , distilled water $-1 \mathrm{dm}^{3}, \mathrm{pH} 7.4$. Incubation was carried out at $37^{\circ} \mathrm{C}$ for $24 \mathrm{~h}$. Two $\mathrm{cm}^{3}$ of suspension was sterile taken from the cultures obtained and transferred to eppendorf tubes. The tubes and the culture were centrifuged at $10.000 \mathrm{rpm}$. for 6-7 minutes using a MiniSpin ${ }^{\circledR}$ centrifuge (Eppendorf). The supernatant was removed and the pellet was suspended in $1 \mathrm{~cm}^{3}$ of diluent, which was peptone water with the composition $\left[\mathrm{g} / \mathrm{dm}^{3}\right]$ : peptone -1 , distilled water $-1 \mathrm{dm}^{3}$. The cell suspension obtained in this way was transferred to a densitometer (Densi-La-Meter®II, Lachema) in order to bring its optical density to 1 , which according to the Mc Farland scale corresponds to $3 \times 10^{8}$ bacterial cells in $1 \mathrm{~cm}^{3}$. Then $20 \mathrm{~cm}^{3}$ of nutrient broth and $0.2 \mathrm{~cm}^{3}$ of previously boiled bacterial suspension were poured into sterile dishes. Sterilized ( $80 \%$ ethanol) and dried with sterile paper fragment of the tested film with dimensions of $0.5 \times 1.5 \mathrm{~cm}$ were placed in the prepared dishes. The whole was incubated at $35^{\circ} \mathrm{C}$ for $48 \mathrm{~h}$. Then the film fragments were gently washed three times with distilled water to remove unbound cells and dried in air for 30-45 minutes. After this time, the films were flooded with $1 \%$ crystal violet and left for 45 minutes - violet binding by the resulting biofilm. Then, to remove unbound violet, again washed three times with distilled water and dried for 30 minutes. Further, the film fragments were placed in chemically clean tubes and filled with $2.5 \mathrm{~cm}^{3}$ of ethyl alcohol (96\%). The whole was sealed with parafilm to prevent evaporation of alcohol and vortexed - extraction of violet bound by biofilm. After washing the crystal violet, the resulting alcohol solution was placed in a spectrophotometer and the absorbance measured at wavelength $\lambda=595$. The measurements were made in triplicate for each of the trials.

Determination of bacterial biofilm by live/dead method was performed using ECLIPSE 50i fluorescence microscope (Nikon, Japan). Fragments of $1.5 \mathrm{~cm} / 1.5 \mathrm{~cm}$ film were placed in $15 \mathrm{ml}$ plastic tubes, all mounted on a laboratory shaker for 7 days. The test was carried out at $35^{\circ} \mathrm{C}$. After this incubation time, the film was gently washed with distilled water. On the dried film, 1 drop of a fluorochrome mixture (SYTO9 and propidium iodide) was applied. After 20 minutes, the films were rinsed with distilled water and dried. The film fragments were then applied to a black slide. The preparation was viewed under a 100x magnification lens.

Material structure analysis and biofilm identification on PLA was performed using a scanning electron microscope 


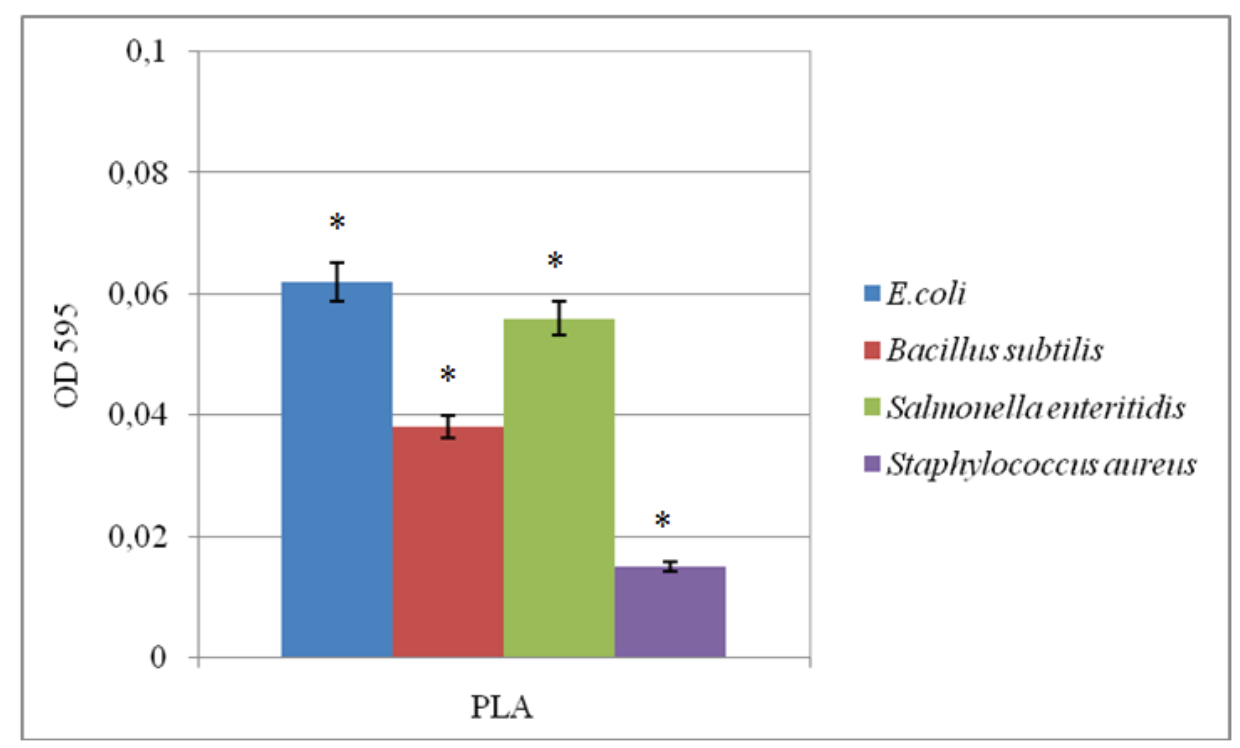

Figure 2. The abundance of E. coli, B. subtilis, S. enteritidis, and S. aureus bacterial biofilm on PLA film surface determined by spectrophotometric measurement of the amount of bound crystal violet $(*$ the results are statistically significant)

(HITACHI SU 8010, Hitachi High-Technologies Co.). The tests were carried out to determine the changes in morphology of the film surface after 7 days of incubation in the compost extract. In order to achieve the best quality photos, the film samples were previously sprayed with $\mathrm{Au} /$ Pd alloy. Pictures taken at 1000x, 3000x and 5000x magnification.

\section{Results}

The results of bacterial biofilm determination on PLA film by spectrophotometric measurement are shown in Figure 2.

The analyzes showed that all the analyzed bacterial strains formed a biofilm, which was the largest for $E$. coli and S. enteritidis, the smallest for B. subtilis and S. aureus. The amount of biofilm formed by $S$. aureus bacteria on PLA film was about four times smaller than that of E. coli. The ability of the tested bacterial strains to form a biofilm can be ranked as follows: $E$. coli $>S$. enteritidis $>$ B. subtilis $>S$. aureus. However, regardless of the bacterial strain used, a biofilm was formed on the surface of the polylactide film, which may indicate that the film is biodegradable.

Due to the fact that the largest amount of biofilm on PLA above (0.06 OD) was produced by the E. coli strain, the next figure (Fig. 3) shows the results of bacterial biofilm ( $E$. coli) determination using the LIVE/DEAD fluorescence microscope for this bacterium. Under the influence of the used fluorochromes, green stained bacterial cells are visible (marked with a white arrow). This result indicates the viability of bacterial cells and the formation of biofilm on the tested film surface. A small number of dead bacterial units were found, colonies stained orange (marked with a red arrow).

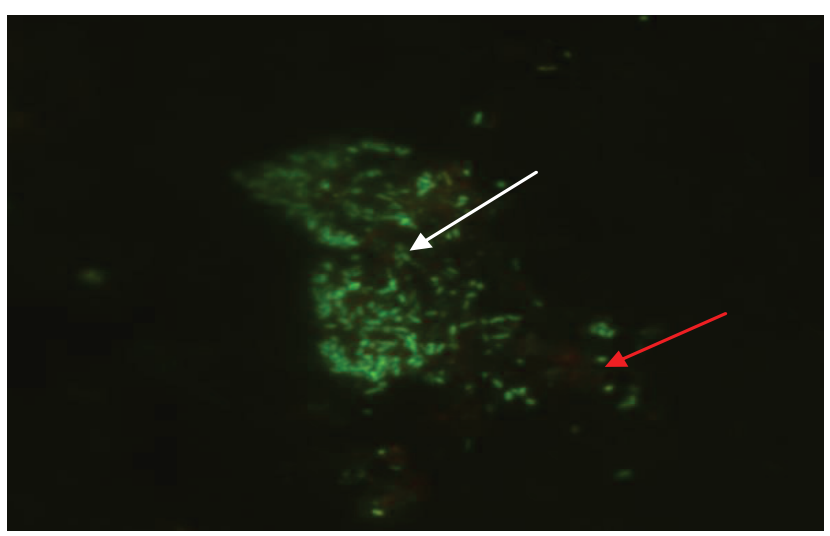

Figure 3. Bacterial biofilm of E. coli on the surface of PLA film after 7 days of incubation with plastic marked by live/ dead technique(green stained bacterial cells - white arrow, colonies stained orange - red arrow)

Changes in the surface structure of the polylactic film after seven days of contact with $E$. coli solution is shown in Figure 4. This drawing shows that after seven days of incubation of the film in the bacterial suspension, the PLA structural surface changes, which was confirmed by film analyzes at 1000x, 3000x and 5000x magnification. The formation of a bacterial biofilm was observed, which covers the entire film surface with varying intensity. In Figure 4 ( $a, b$ c), some forms of the biofilm formed are 

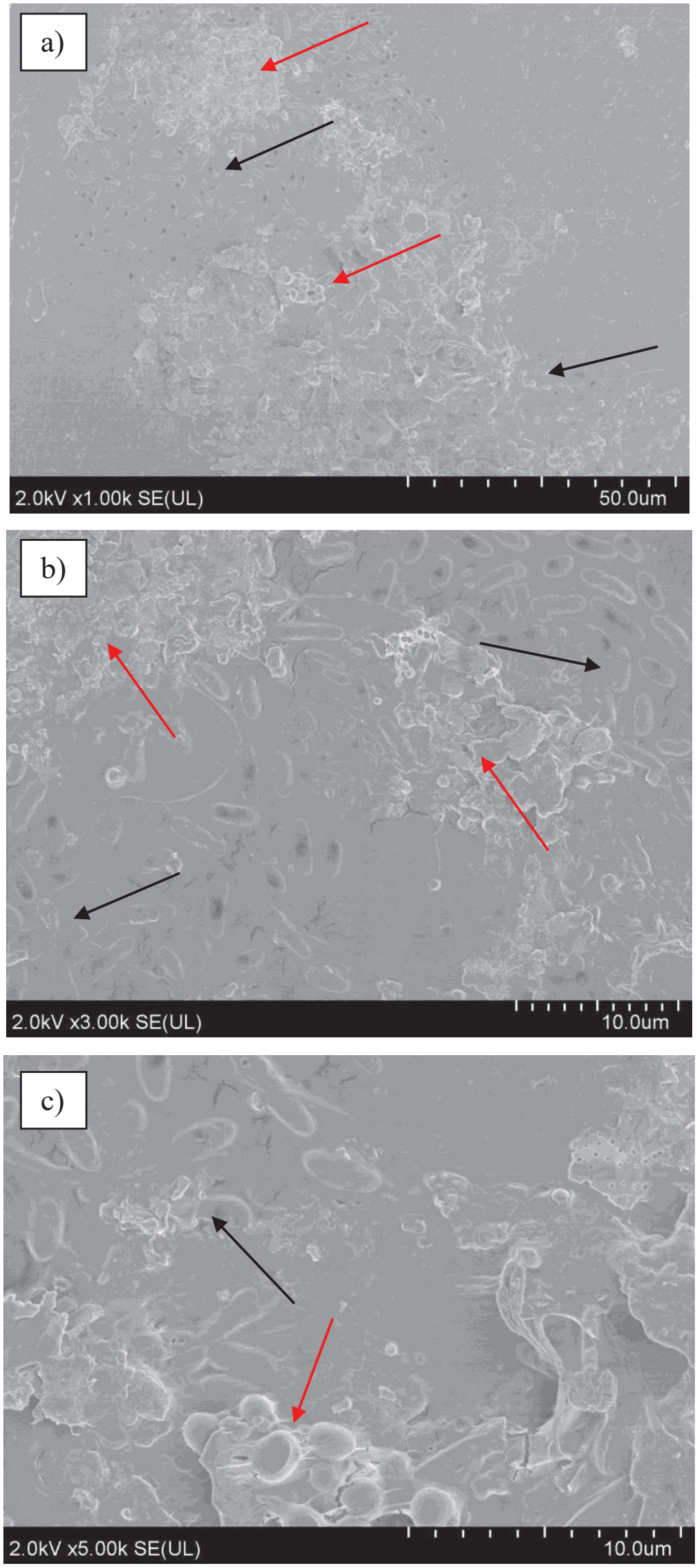

Figure 4. Images of PLA surface and identified biofilm after 7 days of incubation in E. coli solution using a scanning electron microscope, a) magnification 1000x, b) 3000x, c) 5000x (flat biofilm - black arrow, columnar biofilm - a red arrow) 
marked with arrows. The biofilm determination method using a scanning microscope makes it possible to distinguish both flat (marked with a black arrow) and columnar (marked with a red arrow) biofilm types.

\section{Discussion}

Packaging films form an integral part of the finished product and make the product attractive. Packaging must meet more and more different requirements. In addition to its basic functions, it must also be environmentally friendly and easily biodegradable after the end of use (Richert \& Walczak, 2012). The impetus for the development and research on the production of new biodegradable polymeric materials has become legal requirements, an increase in the production of polymer materials or technological progress, as well as an aspect of environmental protection (Żakowska, 2002). Polylactide is one of the more and more frequently used biodegradable polymers (Olewnik-Kruszkowska et al., 2019; Richert et al., 2018; 2019; Richert \& Olewnik-Kruszkowska, 2018; Richert, 2017). The material commonly used in the packaging industry and medicine and modified to change its properties and increase its applicability (Janczak et al., 2016a; Raszkowska-Kaczor et al., 2017).

A key aspect in biodegradation processes is the ability to create bacterial biofim on a given surface. Bacterial biofilm is a structure that protects cells from bactericidal substances. In addition to its protective function, it also plays a huge role in the initial biodegradation phase. Contamination of polymeric materials is the beginning of biodegradation (Kania-Surowiec, 2013). The processes of destruction of materials that occur under the influence of biological activity are referred to as biodeterioration or corrosion caused by microorganisms (MIC-microbiologically influence corrosion). Colonization of the surface of materials is easier when, due to the action of wind, water and air pollution, there is a violation and damage to the structure (Kołwzan, 2011). Water easily gets into the damage, which contributes to the settlement of microorganisms on the surface of the material. Initially, it is covered with individual cells, but over time, they begin to multiply and form colonies, from which a mature form of biofilm is formed (Czaczyk \& Wojciechowska, 2003).

Different groups of microorganisms can break down or transform organic compounds into simpler substances. Microorganisms and their enzymes as well as external factors such as oxygen concentration and biofilm density affect the processes and rate of decomposition of a given organic material (Kania-Surowiec, 2013). Examples are bacterial strains Serratia plymuthica and Arthrobacter sp. (Janczak \& Dąbrowska, 2018; Janczak et al., 2018; Janczak et al., 2016b) and fungi Trichoderma viride (Znajewska et al.,
2018) microorganisms capable of producing hydrolytic enzymes and forming biofilm on PLA and polyethylene terephthalate (PET).

One method of studying bacterial biofilm is spectrophotometric measurement of the amount of bound crystal violet by biofilm forming bacterial cells (Kroupitski et al., 2009; Sela et al., 2006; Stepanovic et al., 2000). The above method is commonly used to analyze biofilm (Janczak \& Dąbrowska 2018; Janczak et al., 2018; Walczak et al., 2015). The research presented in this work shows that the formation of biofilm by E. coli and S. aureus, B. subtilis, $S$. enteritidis on the tested films is not limited. PLA film did not inhibit Gram-negative and Gram-positive bacteria. Available literature data shows that Gram-negative bacteria more easily form a biofilm due to the presence of lipopolysaccharide (LPS) in their outer shells. LPS due to its properties facilitates cell adhesion to the surface and initiation of processes related to biofilm formation (Berdychowska et al., 2019; Karatan \& Watrick, 2009; Hoffman et al., 2005; Hall-Stoodley et al., 2004).

Adhesion of microorganisms on the film surface during biodegradation was observed in the SEM method. Most biological material was observed on PLA film after incubation with E. coli suspension, while the least on PLA samples after incubation with $S$. aureus suspension. Shah et al. (2008) used the SEM technique to analyze the effects of polymer material decomposition under the influence of soil environment. These authors described the course of degradation after 120 days of incubation in soil as changes in the structure of the film. This was evidenced by the clear rough surface or grooves that were the result of the action of microorganisms. Molitoris et al. (1996) also noticed numerous forms of biofilm formation on polymeric material. Janczak et al. (2016a) analyzed the biofilm created by 18 bacterial strains in order to select microorganisms capable of biodegradation PLA and PET. The results of scanning electron microscopy of biofilm formation on the surface of polylactide film are also known (Strömberg \& Karlsson, 2009; Hakkarainen et al., 2000). The results of our research carried out using SEM confirmed the above observations, the presence of a biofilm formed by the E. coli strain was found on the PLA film.

Bacterial cells with a biofilm can also be analyzed for their viability using epifluorescence microscopy. In this case, the so-called live/dead test, staining with fluorochromes both live (green) and dead (red) cells present on the polymer material (Zhou et al., 2010). In our studies, the biofilm formed on PLA was dominated by live bacterial cells after a seven-day incubation of the strain in the presence of plastic. This suggests that this strain may contribute to the formation of degradation changes on the material and lead to changes in its properties.

Bacterial biofilm can be determined using a variety of research techniques, each of which at different angles rep- 
resents the abundance and formation of a bacterial biofilm. Each of them has a slightly different view on the problem of microbial film formation (Richert et al., 2013). To sum up, the method of determining the biofilm abundance by spectrophotometric measurement of the amount of bound crystal violet by bacterial cells allows the quantitative determination of biofilm. It is a relatively simple technique and enables quick analysis of many bacterial strains simultaneously. Therefore, it can be used in screening to identify strains effective in biodegradation of plastics. In turn, the live/dead test and the SEM technique are qualitative methods that allow for detailed analysis and characterization of bacterial biofilm.

\section{Conclusions}

Bacterial biofilm is successfully produced by both Gram positive and Gram negative bacteria on the polylactide surface. Of the four bacterial strains used, Escherichia coli showed the highest biofilm formation capacity. Quantitative and qualitative techniques used to determine the abundance of bacterial biofilm are effective and reliable when it is determined on PLA film. Each of the top used methods provides new data that gives a different view on the described topic which is biofim.

\section{References}

Baranowska K. \& Rodziewicz A., 2008, Molekularne interakcje w biofilmach bakteryjnych [Molecular interactions in bacterial biofilms]. Kosmos 1(2): 29-38.

Berdychowska J., Boniecka J. \& Dąbrowska G.B., 2019, Odpowiedź ścisła i jej zaangażowanie w reakcje komórek bakteryjnych na stresy [The stringent response and its involvement in the reactions of bacterial cells to stress]. Postępy Mikrobiologii [Advancements of Microbiology] 58(2): 127-142.

Czaczyk K.\& Myszka K., 2012, Charakterystyka zjawiska quorum sensing i jego znaczenie w procesach mikrobiologicznych [Characteristics of the quorum sensing phenomenon and its significance in microbiological processes]. Ochrona przed Korozją 9s/A: 16-19.

Czaczyk K. \& Wojciechowska K., 2003, Tworzenie biofilmów bakteryjnych-istota zjawiska i mechanizmy oddziaływania [Bacterial biofilm formation - the essence of the phenomenon and mechanisms of interaction]. Biotechnologia 62: 180-192.

Dąbrowska G., Prusińska J. \& Goc A., 2006, Odpowiedź ścisła - mechanizm adaptacyjnej odpowiedzi bakterii na warunki stresowe [Exact response - the mechanism of bacterial adaptive response to stress conditions]. Postępy Biochemii 52 (1): 87-93.
Flemming H.C. \& Wingender J., 2010, The biofilm matrix. Nature Review Microbiology 8: 623-633.

Hakkarainem M., Karlsson S. \& Albertsson A.C., 2000, Rapid (bio) degradation of polylactide by mixes culture of compost microorganisms-low molecular weight products and matrix changes. Polymer 41: 2331-2338.

Hall-Stoodley L., Costerton J.W. \& Stoodley P., 2004, Bacterial biofilms: from the natural environment to infectious diseases. Nature Review Microbiology 2: 95-108.

Hoffman L.R., D’Argenio D.A., MacCoss M.J., Zhang Z., Jones R.A. \& Miller S.I., 2005, Aminoglycoside antibiotics induce bacterial biofilm formation. Nature 7054 : 1171-1175.

Janczak K. \& Dąbrowska G., 2018, Bakterie zdolne do biodegradacji polilaktydu i polikaprolaktonu [Bacteria able to polylactide and polycaprolactone biodegradation]. Przemysł Chemiczny 97 (3): 435-438.

Janczak K., Hrynkiewicz K., Znajewska Z. \& Dąbrowska G., 2018, Use of rhizosphere microorganisms in the biodegradation of PLA and PET polymers in compost soil. International Biodeterioration \& Biodegradation 130: 65-75.

Janczak K., Raszkowska-Kaczor A., Stasiek A. \& Dąbrowska G., 2016a, Wybrane modyfikacje polilaktydu (PLA) ze szczególnym uwzględnieniem procesu porowania [Selected modifications of polylactide (PLA) with particular emphasis on the poring process], [in:] J. Kujawski, J. Doskocz (eds) Innowacje w polskiej nauce: przegląd aktualnej tematyki badawczej branży chemicznej [Innovations in Polish science: a review of current research topics of the chemical industry]. Wydawnictwo Naukowe Sophia, Katowice, p. 59-65.

Janczak K., Znajewska Z., Narbutt O., RaszkowskaKaczor A. \& Dąbrowska G., 2016b, Serratia sp. jako składnik preparatów wspomagających degradację PLA i PCL [Serratia sp. in the PLA and PCL-supporting biodegradation preparations]. Przemysł Chemiczny 95(5): 943-947.

Kania-Surowiec I., 2013, Złoża biologiczne w oczyszczaniu ścieków z recyklingu tworzyw sztucznych [Biological deposits in wastewater treatment from plastic recycling]. Inżynieria Ekologiczna 32: 74-84.

Karatan E. \& Watnick P., 2009, Signals, regulatory networks, and materials that build and break bacterial biofilms. Microbiology and Molecular Biology Review 2: 310-347.

Kołwzan B., 2011, Analiza zjawiska biofilmu - warunki jego powstawania i funkcjonowania [Analysis of the biofilm phenomenon - conditions for its formation and functioning ]. Ochrona Środowiska 4: 3-14.

Kroupitski Y., Pinto R., Brandl M.T., Belausov E. \& Sela S., 2009, Interactions of Salmonella enteric with lettuce leaves. Journal of Applied Microbiology 106/6: 1876-1885. 
Kunicki-Goldfinger W.J.H., 2008, Życie bakterii [Bacteria life]. Wydawnictwo Naukowe PWN, Warszawa.

Molitoris H.P., Moss S.T., de Koning G.J.M. \& Jendrossek D., 1996, Scanning electron microscopy of polyhydroxyalkanoate degradation by bacteria. Applied Microbiology and Biotechnology 46: 570-579.

Olewnik-Kruszkowska E., Tarach I., Richert A., Cichosz M., Koter I. \& Nowaczyk J., 2019, Physicochemical and barier properties of polylactide films including antimicrobial additives. Materials Chemistry and Physics 230: 299-307.

Raszkowska-Kaczor A., Stasiek A., Janczak K., Dąbrowska G. \& Kaczor D., 2017, A extrusion process of foaming PLA intended for subsoil for microorganisms, [in:] J.W. Sikora, O. Suberlyak (eds) Technological and design aspects of extrusion and injection moulding of thermoplastic polymer composites and nanocomposites: monography vol. 5, Lviv Polytechnic National University, Lublin University of Technology, Lviv, pp. 88-101.

Richert A., 2017, Polymeric materials - selected standards and biological research methods. World Scientific News 76: 166-17.

Richert A. \& Olewnik-Kruszkowska E., 2018, Enzymatic degradation of biostatic materials based on polylactide. Ecological Questions 29/2: 91-97.

Richert A., Olewnik-Kruszkowska E., Adamska E. \& Tarach I., 2019, Enzymatic degradation of bacteriostatic polylactide composites. International Biodeterioration Biodegradation 142: 103-108.

Richert A., Olewnik-Kruszkowska \& Tarach I., 2018, Growth of selected fungi on biodegradable films. Ecological Questions 29/4: 63-68.

Richert A. \& Walczak M., 2012, Effect of polyhexamethyleneguanidine derivatives on melt flow rate and susceptibility on biodegradation of polylactide composites. Przemysł Chemiczny 8: 1617-1620.

Richert A., Walczak M. \& Swiontek Brzezińska M., 2013, The influence of modified polyhexamethylene guanidine on the biodegradation of polylactide. International Biodeterioration \& Biodegradation 84: 97-103.
Sela S., Frank S., Belausov E. \& Pinto R., 2006, A mutation in the luxS gene influences Listeria monocytogenes biofilm formation. Applied and Environmental Microbiology 72/8: 5653-5658.

Shah A.A., Hasan F., Hameed A. \& Ahmed S., 2008, Biological degradation of plastics: A comprehensive review. Biotechnology Advances 26: 246-265.

Stepanovic S., Vukovic D., Dakic I., Savic B. \& SvabicVlahovic M., 2000, A modified microtiter-plate test for quantification of staphylococcal biofilm formation. Journal of Microbiological Methods 40(2): 175-179.

Strömberg E. \& Karlsson S., 2009, The effect of biodegradation on surface and bulk property changes of polypropylene, recycled polypropylene and polylactide biocomposite. International Biodeterioration \& Biodegradation 63: 1045-1053.

Trafny E.A., 2000, Powstawanie biofilmu Pseudomonas aeruginosa i jego znaczenie w patogenezie zakażeń przewlekłych [Biofilm formation of Pseudomonas aeruginosa and its role in the pathogenesis of chronic infections]. Postępy Mikrobiologii 39: 55-71.

Walczak M., Świontek Brzezińska M., Richert A. \& Kalwasińska A., 2015, The effect of polyhexamethylene guanidine hydrochlorideon biofilm formation on polylactide and polyhydroxybutyrate composites. International Biodeterioration \& Biodegradation 98: 1-5.

Zhou Z.X., Wie D.F., Guan Y., Zheng A.N. \& Zhong J.J., 2010, Damage of Escherichia coli membrane by bactericidal agent polyhexamethylene guanidine hydrochloride: micrographic evidences. Journal Applied Microbiology 108(3): 898-907.

Znajewska Z., Dąbrowska G.B., Hrynkiewicz K.L. \& Janczak K. 2018, Biodegradacja polikaprolaktonu przez grzyby Trichoderma viride [Biodegradation of polycaprolactone by Trichoderma viride fungi]. Przemysł Chemiczny 97(10): 1676-1679.

Żakowska H., 2002, Opakowania, a odpady opakowaniowe. Poradnik. Obowiązki wynikające z nowych regulacji prawnych [Packaging and packaging waste. Guide. Obligations arising from new legal regulations]. ODDK Sp. z o.o., Gdańsk. 